\title{
Os limites do realismo artístico em Pedro Páramo, de Juan Rulfo
}

\author{
José Alberto Miranda Poza* \\ Thiago da Camara Figueredo**
}

\begin{abstract}
Resumo
À luz da Teoria da Literatura, este ensaio indaga o conceito de realismo artístico na ficção a partir da discussão sobre referente e signo linguístico, tendo como base a categoria de representação social de Luiz Costa Lima $(1981 ; 1974)$ e a teoria do efeito estético de Wolfgang Iser (2002). O ponto de chegada diz respeito à aproximação entre a concepção de realismo artístico desenvolvida pela reflexão teórica e os traços constituintes descobertos através da análise do romance Pedro Páramo, de Juan Rulfo (1985), com a finalidade de avaliar que elementos são essenciais para se caracterizar uma obra como realista.
\end{abstract}

\section{Palavras-chave}

Teoria da Literatura, realismo artístico, ficção, Pedro Páramo.

A realidade e o real não se confundem. Se a primeira diz respeito ao espaço empírico no qual os seres se constituem vivos, é o segundo que oferece as diretrizes necessárias para tal reflexão. O princípio não é o verbo. O verbo assinala a ilusão ontológica, como se a nomeação mundo pudesse substituir a essencialidade do que quer que seja mundo. Uma vez que a posse do nome não engendra o objeto, resta ao homem conhecer o que se sabe das coisas ao invés das coisas em si. Mas o princípio é o verbo, pois sendo a ontologia sequer delineável, só através dele se produz o questionamento da impossibilidade. O verbo se torna, assim, o veículo de acesso ao templo das convenções de significação do mundo - o real. Se no plano da realidade o homem vive, é no plano do real que se torna humano.

O objetivo da discussão teórica que aqui se empreende é refletir sobre o que torna uma obra realista, tanto em relação ao conjunto de procedimentos artísticos quanto ao conjunto de critérios teóricos. Especial referência se fará à consideração

\footnotetext{
* José Alberto Miranda Poza é Doutor em Filologia e Letras e Professor Adjunto da Universidade Federal de Pernambuco.

** Thiago da Camara Figueredo é mestrando em Letras, área Teoria da Literatura, pela Universidade Federal de Pernambuco.
} 
sobre a mímesis, apoiada nas investigações de Costa Lima $(1981 ; 1974)$ e, sobretudo, na Teoria do Efeito Estético de Iser (2002). Inicialmente, parte-se de uma investigação do conceito de referente e de seu desdobramento em signo linguístico, se é ele natural ou mediado, e, consequentemente, da relevância de sua definição para considerar a ação da Literatura. A obra literária já foi acusada de falsear o real devido à execução de uma cópia distante da verdade, mas foi também exaltada por construir um mundo autônomo em relação ao que lhe é exterior. A análise dos mecanismos de constituição do referente tem o mérito de dialogar com as duas perspectivas e é extremamente relevante para que se defina a abrangência do adjetivo realista para determinados tipos de textos. Uma vez que se busca problematizar diferentes concepções do realismo artístico, é imprescindível sinalizar e refletir a variedade de abordagens que trataram o termo à luz da Teoria da Literatura, ainda que o ponto de chegada do ensaio consista no diálogo entre a discussão teórica desenvolvida e uma obra particular do cânone ocidental, que é Pedro Páramo (1985), de Juan Rulfo.

Historicamente, foi com o surgimento da Lingüística que se aprendeu o caráter arbitrário do processo de significação. Sausurre (apud CULLER, 1999, p. 63) teve o mérito de destacar a artificialidade do signo linguístico ao rejeitar a concepção natural de correspondência entre o significante e o significado. Somam-se a tal argumento a constatação já clássica de que se a linguagem remetesse à ontologia do objeto, então não haveria diversas línguas, mas uma única, dada a capacidade do homem de nomear a essência das coisas; a hipótese Sapir-Whorf (CULLER, 1999, p. 62), que através da Linguística Comparada defendeu que aquilo que se pensa é em ampla medida determinado pela língua que se fala; as contribuições da psicologia ao investigar os casos das crianças selvagens, os quais, restituídos da interação com os outros, não desenvolveram linguagem humana.

É o último exemplo o ponto de partida de Blikstein (1995) para analisar os mecanismos de fabricação do real. O linguista parte de uma concepção imotivada do signo linguístico, porém, ou mesmo por isso, rejeita o triângulo tradicional da Linguística, que estabelecia uma relação direta, ainda que arbitrária, entre referente, signo e significado. Da exemplificação do caso factual de Kaspar Hauser, indivíduo criado até quase a maior idade em um vão de um prédio e sem interação humana, Blikstein (1995) elabora sua teoria de produção do real ao constatar que, a partir do momento em que Hauser é resgatado de seu cativeiro e inserido na comunidade, o acesso ao código linguístico vigente não garante por si só o sucesso nas interações sócio-comunicativas mais elementares. Hauser se torna uma ameaça a sua comunidade devido a sua incapacidade de significar eficientemente o mundo a sua volta, pois não detém as formas habituais de pensar e agir, desfazendo as convenções.

O fracasso de Kaspar Hauser evidencia que ao referente não corresponde um dado extralinguístico objetivo. O referente, na verdade, é visto por Blikstein (1995) como um produto resultante das esferas de percepção e cognição modelado pela práxis social e que tem na língua seu mecanismo de expressividade e reatualização. 0 quadro de Blikstein (1995, p. 81) pode auxiliar a explicação: 


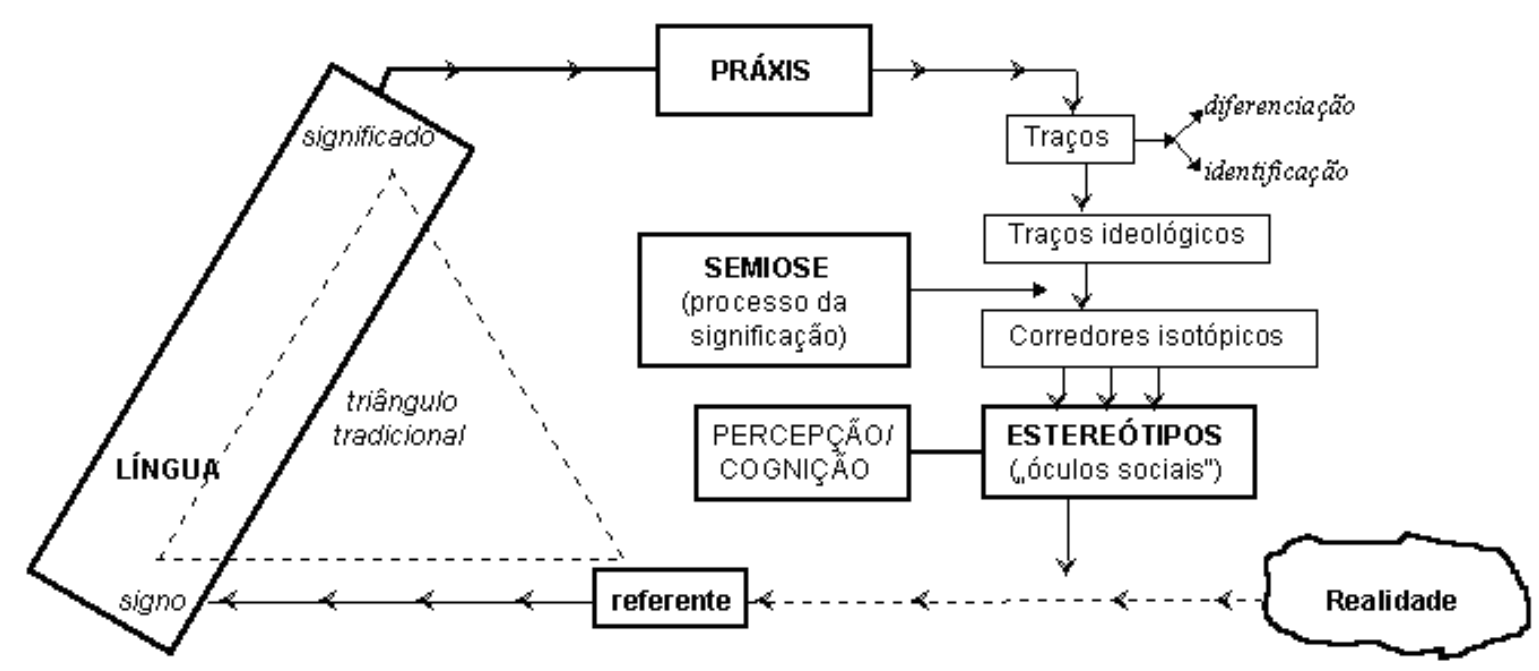

É a práxis social que orienta o processo de significação materializado pela linguagem ao fornecer o conjunto das formas de ver, sentir e avaliar (grosso modo, a ideologia). Entretanto, a linguagem não desempenha papel secundário nesse processo, pois se é previamente orientada pela práxis social, a posteriori, passa a modelá-la.

O efeito da última constatação se bifurca: a) esclarece a impropriedade de um tratamento direto entre referente extraverbal e signo linguístico pela ação dos sistemas de percepção e cognição; b) impede o restabelecimento da ideia de essencialidade ao revelar a flexibilidade de tais sistemas pela atuação da linguagem na prática social. Sua principal consequência para a reflexão sobre a Literatura é a reinterpretação do trabalho da poesia. A concepção essencialista de arte tratou o texto literário como cópia de algo exterior, confundindo o valor do texto com a fidelidade à verdade externa, fosse ele um espelho da sociedade ou da inteligência criadora; servem como exemplo grande parte dos romances vinculados às escolas romântica, realista-naturalista e regionalista, tal como surgiram na América Latina e no Brasil. Comprovada a impossibilidade de se acessar a essência das coisas, portanto, sua verdade, e evitando-se o impressionismo compensatório, é momento de investigar o funcionamento dos mecanismos de produção dos referentes.

Lima (1981) reconhece que as formas de entendimento pressupõem uma abrangência que nem apenas os sentidos (esfera perceptiva) ou a consciência (esfera cognitiva) conseguem dar conta, uma vez que social (práxis). O teórico recorre à Sociologia e à Antropologia para defender que todo o tipo de classificação (signo linguístico) corresponde a uma ordem hierárquica que uma sociedade utiliza para estabelecer e diferenciar valores, o que engendra os processos de identificação. Podese, assim, determinar que as identidades não equivalem à essência, mas às representações legitimadas por tal sociedade. 0 referente deixa de se confundir com o verdadeiro para dizer o representativo. Lima (1981, p. 289) ainda faz a ressalva de que não existe real prévio à representação, mas o contrário, as representações são o que concedem significado ao real. 
As representações são estruturalmente organizadas por "grilles" (redes de classificações) e "frames" (molduras de convenção) que funcionam como o cerimonial social e a vestimenta adequada, respectivamente. São tais estruturas que orientam a interação humana no sentido de torná-la efetiva. Se o comportamento delas é automatizado, entretanto, não se deve supor estanque. Lembre-se: a língua reatualiza a práxis. Concretamente, os "frames" operam por dois processos básicos de flexibilidade: a fabricação e a transposição. Enquanto o primeiro designa a mentira, a fraude, o segundo revela uma desestabilização da moldura básica, quando um indivíduo realiza uma ação que gera um significado diferente daquele que parecia indicar. Essa é a transposição comum ao jogo e aquela que Lima (1981) relaciona à Literatura devido a sua capacidade de destituir o valor pragmático dos enunciados do texto literário, ressignificando-os.

\begin{abstract}
Referindo-nos pois ao que se passa tanto na prosa quanto na poesia, podemos dizer: a mímesis supõe em ação o distanciamento pragmático de si e a identificação com a alteridade captada nessa distância. Identificação e distância, identificação a partir da própria distância constituem pois os termos básicos e contraditórios do fenômeno da mímesis. Pensando-a pois em relação às representações sociais, diremos que ele é um caso particular seu, distinto das outras modalidades porque a mímesis opera a representação de representações. Na fórmula, reencontramos sua propriedade paradoxal. Representação de representações, a mímesis supõe entre estas e sua cena própria uma distância que torna aquelas passíveis de serem apreciadas, conhecidas e/ou questionadas. Essa distância, pois, ao mesmo tempo em que impossibilita a atuação prática sobre o mundo, admite pensar-se sobre ele, experimentar-se a si próprio nele. (LIMA, 1981, p. 230.)
\end{abstract}

Representação de representações, o referente de que se serve a mímesis literária não supõe a cópia de um objeto, cena ou ideia exteriores. O texto artístico deixa de ser uma imagem do mundo para se tornar uma reflexão sobre ele ao cobrar do receptor a alteridade que lhe é ponto de partida. É pelo fingimento que a mímesis faz com que o referente emanado pelo texto estabeleça uma relação com as referências históricas do receptor, assemelhando-se ou distanciando-se das representações vigentes na sociedade deste último.

A relevância da caracterização dos sistemas de representação social tem funções diversas para a presente análise: a) destaca-se o caráter produtivo do real e, portanto, anula-se a possibilidade de buscar-se uma referência objetiva a qual a obra espelha; b) recusa-se o caráter condicionante do externo, que trata a obra como um sintoma da sociedade; c) mas também evita-se uma perspectiva imanente de arte, que vê a obra como autônoma, ausente do mundo.

Entender o texto literário como representação de representações problematiza ainda a motivação primeira desta análise: definir como uma obra se constitui realista. Se a abordagem teórica dos sistemas de representação demonstrou que a mímesis literária guarda um distanciamento e uma proximidade com as representações vigentes na sociedade, isso quer dizer que o real se faz presente em toda a obra literária. Ao se indagar a teoria do efeito estético de Iser (2002), percebe-se que o primeiro passo do objeto literário é a seleção de aspectos do real histórico (seja ele a vida ou a própria Literatura) que serve de ponto de partida do artístico para ser por este combinado em uma estrutura que enquanto finge-se autêntica, desnuda-se 
interna e externamente, e então é significada pelo leitor, que projeta sobre a obra o seu sistema de representações. Isso pode ser mais claramente exposto pela contemplação de Os Atos de Fingir ou o que é Fictício no texto Ficcional (ISER, 2002). Nesse texto, Iser (2002) oferece a base de sua reflexão sobre o texto artístico. O teórico sistematiza tais atos em três, sendo a seleção o primeiro deles. Ela dá conta da escolha das referências que serão transformadas pelo texto. De natureza cultural ou literária, os referentes selecionados têm seus valores transgredidos de sua estrutura semiológica habitual. Há de se perceber que a transgressão do ato da seleção impossibilita que se atribua um deslocamento objetivo dos sistemas de referência do mundo extratextual para a atmosfera do texto. As representações que o texto abarca são transgredidas por ele próprio, que suprime, complementa e valoriza tipos determinados de acordo com sua intencionalidade.

$O$ ato transgressor seguinte é a combinação. Ela diz respeito, sobretudo, à organização interna dos elementos textuais, tanto no nível do enunciado quanto na organização da intriga, e interage com o ato da seleção para construir no corpo do texto o sistema de valores almejado por sua intencionalidade. Dessa forma, a combinação se caracteriza pela criação de relacionamentos intratextuais que não se esgotam dentro do texto. Ela deixa de funcionar como um único relacionamento para se constituir como representação de relacionamentos.

O último ato de fingir é denominado desnudamento da ficcionalidade. Ele é responsável pela diferenciação entre a Literatura e a realidade; defende que os textos literários se apresentam historicamente como ficção a partir de um conjunto de convenções que autor e leitor compartilham. Pode-se dizer que o texto ficcional, ao produzir um mundo, não espera ser tomado como dado, empírico, mas como se fosse real. Isso é possível porque o mundo extratextual retorna como algo reconhecível ainda que o texto subtraia o valor pragmático do conjunto de ações de que se serve para ressignificá-lo e revelar um mundo outro, transgredido pelos atos, que, ao guardar uma relação com o real, finge-se autônomo. A autonomia do texto é só aparente, uma vez que seu sentido não pode ser alcançado pela análise exclusiva do eixo sintagmático. De outra forma, privilegiar-se-ia o princípio da combinação sobre os outros, quando, na verdade, os três atos de fingir interagem entre si. Em busca do sentido do texto, é preciso investigar que valores históricos são selecionados por ele e o que o texto faz com tais valores; além disso, não se deve deixar de atentar que esse tipo de investigação só pode ser feita pela observação especial da linguagem do texto, sua concretude, a matéria que transmite seu significado. Obter-se-ia então o mundo do texto, mas não o seu significado. Se o texto se apresenta como o análogo de um mundo, como se fosse real, seu caráter de fingimento estabelece uma relação comparativa com o mundo do receptor que o acolhe, atuando neste encontro uma semelhança e uma diferença entre os sistemas de valores do texto e os sistemas do leitor histórico. Nas palavras de Iser (2002, p. 976 - 977):

O mundo representado no texto é uma materialidade que, por seu caráter de como se, não traz em si mesmo nem sua determinação, nem sua verdade, que devem ser procuradas e encontradas apenas em relação com algo outro. Desta maneira, conserva-se formalmente no texto um elemento designativo. Este, entretanto, já 
não é puramente designativo, porquanto sua função aparece relacionada à função remissiva. Pois, se o como se assinala que o mundo representado deve ser visto como se fosse um mundo, então é necessário manter um certo grau de designação para que o mundo se possa transformar na condicionalidade intencionada.

Para Iser (2002), o texto não pode designar a si mesmo devido ao efeito do como se, mas apenas remeter aquilo que não é, uma vez que não é um mundo real, embora assim seja considerado. A remissão prepara o texto para a sua finalidade: tornar-se perceptível ao promover respostas afetivas nos leitores e assim orientar reações sobre o mundo do texto. Sendo o mundo do texto irrealizado, porém análogo - exemplo do mundo -, o texto provoca "uma relação de reação quanto ao mundo" (ISER, 2002, p. 978).

Podem resultar do breve exposto as seguintes constatações: toda obra é realista, visto que tanto na produção quanto na recepção do texto, os valores do real histórico se fazem presentes e são necessários para a sua significação; a obra realista é aquela em que o vetor proximidade predomina em detrimento do vetor distanciamento, ou seja, quando a representação confeccionada pelo texto estabelece uma semelhança significativa com as representações vigentes na sociedade, ou seja, com aquilo que dada sociedade entende como real, para que se abarque um sentido. Conclusões demasiado apressadas, elas encerrariam o trabalho do poético no eixo da seleção que desenvolvera Iser (2002, p. 960). Se é possível pensar no realismo artístico como unidade, faz-se necessária a busca das categorias estruturais que caracterizam uma obra como realista. Parece mais proveitoso agora revisar alguns estudos teóricos que trataram o realismo artístico para então retomar as constatações prévias e ressubmetê-las a teste.

Para Jakobson (1978), o termo realismo em arte teve a infelicidade de ter sido empregado desordenadamente. O teórico declara que o realismo "é uma corrente artística que propôs como seu objetivo reproduzir a realidade o mais fielmente possível e que aspira ao máximo de verossimilhança" (JAKOBSON, 1978, p. 120). Ciente da diversidade de perspectivas que envolvem a noção de realidade e principalmente o conceito de verossimilhança, Jakobson (1978) sistematiza o realismo em cinco categorias, quais sejam:

a) Uma obra se torna realista como resultado da prefiguração autoral. Atente-se aqui para o caráter imanente da obra. Além disso, o teórico percebe que quando da renovação de uma determinada escola, os artistas se dividem em A1 (os inovadores, reconhecem a deformação do cânone como verossímil) e A2 (conservadores, fieis à tradição, recusam a novidade);

b) Uma obra se torna realista a partir do julgamento do receptor. O realismo se confunde com a impressão do leitor. A esta categoria também correspondem B1 (leitores inovadores) e B2 (leitores conservadores);

c) Realista é a obra do século XIX que apresenta o conjunto dos traços característicos da Escola Realista. Tais obras passam então a servir de paradigma para avaliar o nível de realismo de todos os textos;

d) A utilização de traços não essenciais à intriga confere o realismo de uma obra; 
e) O caráter realista de uma obra é garantido pela existência de uma motivação consequente que justifica as construções poéticas. Elabora-se aqui uma aproximação entre realismo e verossimilhança interna.

Jakobson (1978) denuncia a irresponsabilidade da crítica que por vezes toma uma categoria pela outra ( $B 1$ por $C, C$ por $D$, por exemplo) e embora defenda que 0 realismo artístico possui uma certa significação, um fator comum, não o elabora, mas aconselha o analista a definir com clareza o que trata por realismo. A opção de Jakobson (1978) pela polivalência do realismo artístico e o abandono da investigação de um conceito fundamental de realismo não deve desestimular sua procura. O limite de Jakobson (1978) parece ser sua própria teoria do discurso literário. Se o teórico é capaz de identificar o mecanismo de desautomatização com que o texto poético opera sobre as formas convencionais da comunicação, o produto do desvio tem seu efeito diminuído por se resumir ao prolongamento da perceptibilidade. Ignora-se qualquer correlação que a desautomatização estruturada no texto estabeleça com o sistema de convenções (portanto, representação) da sociedade. O estranhamento que o texto suscita se converte em fruição barata, ponto de chegada do prazer desinteressado. A conotação se transforma em princípio matriz para o estabelecimento da expressividade e o olhar que a ela se dirige converte o texto num sistema fechado. A obra toma a forma de um calabouço.

É a partir da releitura de estudos representativos sobre o realismo artístico e da recusa das sistematizações adjetivas que subverteram o entendimento do tal conceito (alto, histórico, pictórico etc.) que Lima (1974) promete elaborar uma definição própria ao termo realismo. O teórico critica Lukács por considerar que este converte o realismo na literariedade da obra, determinando como função da poesia a revelação das estruturas de poder; cobrando do texto uma atitude reacionária em relação aos conflitos sociais. Para Lima (1974, p. 29), o erro de Lukács se deve a uma concepção reducionista do marxismo, que terminou por caracterizar a arte por seu conteúdo. Sobre Jakobson, Lima (1974, p. 34) não vai além da referência à elaboração sistemática do autor eslavo. O próximo passo do analista (LIMA, 1974, p. 31-33 \& p. 35-37) é refletir o trabalho de Auerbach, sobretudo, a obra Mimesis. Lima (1974) considera que Auerbach define o realismo como a característica específica à Literatura, isto é, gerada em seu interior. A Literatura representa uma concepção do homem que não poderia ser dada de outra forma. O realismo se verifica pela postulação de um destino ao caráter do personagem, o que equivale a considerar o realismo em Auerbach como coerência de construção, aproximando-se da categoria "E" descrita por Jakobson. Entretanto, Lima (1974) argumenta que a empreitada de Auerbach é devedora de uma instrumentalização mais eficiente da correlação entre as séries literárias e não literárias. Por não delimitar satisfatoriamente o sistema da obra, a aproximação entre as séries histórica e literária no Mimesis de Auerbach acaba por conceber o texto artístico como uma realidade derivada da história social.

A insatisfação de Lima (1974) quanto à delimitação dos sistemas dos textos literários em Auerbach se comunica nesta análise com duas constatações anteriormente aqui elaboradas. Enquanto a primeira supunha o realismo como categoria fundamental a todas as obras (perspectiva na qual em certo sentido se 
encontra Auerbach, ainda que lance mão de uma abordagem elástico do conceito), a segunda caracterizava como realista uma obra em que sua representação fosse marcada pela semelhança em relação às representações sociais. As duas suposições foram abandonadas por limitarem o literário ao eixo da seleção (ISER, 2002), ignorando-se, no caso da primeira, a mediação que o imaginário opera ao completar os vazios do texto; no caso da segunda, a materialidade linguística que constitui os textos poéticos.

Se os textos literários executam uma representação de representações, a forma de acesso a eles é, a priori, exclusivamente linguística. A priori, porque o texto poético não tem sua expressividade encerrada no material impresso. O signo linguístico representa a codificação do referente em signo semiológico, isto é, cultural. Por isso, Lima (1974, p. 17) defende que não se pode limitar o signo à cena do dito, de modo que se deve desconstituir a cadeia sintagmática para que seja possível descobrir as relações estabelecidas no eixo paradigmático. Faz-se necessário indagar como os elementos linguísticos se estruturam de modo a expressar as representações. Dito de outro modo, como o princípio de combinação (ISER, 2002, p. 965), isto é, a criação de relacionamentos textuais intrínsecos, se comunica com as representações, formando um todo significativo. Para Lima (1974, p. 42), "realistas são os textos em que o referencial codivide sua importância com a codificação verbal. O que vale dizer, em que o sentido não é captável sem o conhecimento dos sistemas simbólicos não verbais aí presentes". O teórico vai além e declara: "o discurso literário pode ter como cena uma realidade próxima ou distante, extraverbal ou verbal, cultural ou literária. Caracterizamos a expressão realista como aquelas em que os traços realidade próxima, extraverbal e cultural preponderam" (LIMA, 1974, p. 43).

A conclusão a que chega Lima (1974) parece a mais coerente por considerar o aspecto material do texto poético e sua comunicação com o sistema de representações sociais, libertando a análise literária do arcabouço formalista/estruturalista, mas também da teoria do reflexo da Sociologia da Literatura. A sugestão de Lima (1974) aglutina as potencialidades de ambas as formas de interpretação do discurso literário, tratando a referência histórica e a organização estrutural do texto como unidade significativa. Suplementa-se agora a segunda constatação do realismo artístico que veio sendo trabalhada: realista é a obra que elabora, a partir de sua estrutura linguística, uma representação própria que se caracteriza pela semelhança às representações históricas da sociedade a qual faz referência e cujo sentido só é alcançado pela análise atenta da relação entre a matéria textual e o contexto de produção da obra, seu real histórico.

Se a definição está retificada, nem por isso deve-se concluir atingido o objetivo deste ensaio. A discussão teórica empreendida até agora teve a validade de refletir os diversos passos que a Teoria da Literatura tem dado na investigação do realismo artístico. É tempo de encontrar o objeto daquela e retestar as concepções alcançadas no diálogo com o texto poético. O passo a passo da análise que se fará de Pedro Páramo (1985), de Juan Rulfo, pretende descrever o sistema da obra para então correlacioná-la com o contexto de produção e refletir a relevância da correlação para a identificação de sua unidade significativa. A escolha da obra de Rulfo, publicada em 
1953, se deve ao fato de ela estar inscrita na tradição do romance realista maravilhoso da América Latina e pelo seu valor de representatividade na literatura ocidental.

Pedro Páramo (a partir daqui apenas PP, para distinguir a obra do personagem) se inicia através do relato memorialista de Juan Preciado (personagem-narrador), o qual, em consequência de uma promessa feita à mãe em seu leito de morte, empreende uma jornada a Comala para conhecer o seu pai, personagem cujo nome é título do livro. A Comala que Juan Preciado encontra é bastante diferente daquela que acreditava existir a partir das rememorações de sua mãe. Lugar inóspito e abandonado, Juan Preciado toma conhecimento da morte de Pedro Páramo, seu pai, já no início da narrativa e chega ao espaço geográfico do que poderia ter sido uma cidade, onde as poucas pessoas com quem dialoga estão mortas. A imagem de Pedro Páramo é então construída pela lembrança de eventos que os outros personagens transmitem a Juan Preciado e pelas interpolações que um segundo narrador oferece sobre a infância e a vida de Pedro Páramo, bem como de outros personagens. Juan Preciado morre em meio a sua jornada e passa a integrar a identidade não usual da cidade. A narração se converte na história de Comala e na reverberação do passado da cidade em seu presente de ruínas.

Da estrutura narrativa de PP, chama a atenção a organização temporal dos eventos da narração. O leitor descobrirá que o Juan Preciado que inicia a história já está sepultado e é de seu túmulo que relembra o seu percurso ao seu narratário explícito: o personagem Dorotea, senhora louca que fora enterrada junto a ele. É ela quem atesta a história de fracasso de Juan Preciado em Comala. Sirva-se de exemplo o contraste entre a Comala das lembranças da mãe de Juan Preciado e a Comala da experiência do personagem:

- ¿Cómo dice usted que se llama el pueblo que se ve allá abajo?

- Comala, señor.

- ¿Está seguro de que ya es Comala?

- Seguro, señor.

- ¿Y por qué se ve esto tan triste?

- Son los tiempos, señor.

Yo imaginaba ver aquello a través de los recuerdos de mi madre; de su nostalgia, entre retazos de suspiros. Siempre vivió ella suspirando por Comala, por el retorno; pero jamás volvió. Ahora yo vengo en su lugar. Traigo los ojos com que ella miró estas cosas, porque me dio sus ojos para ver: 'Hay allí, pasando el puerto de Los Colimotes, la vista muy hermosa de una llanura verde, algo amarilla por el maíz maduro. Desde esse lugar se ve Comala, blaqueando la tierra, iluminándola durante la noche.' Y su voz era secreta, casi apagada, como si hablara consigo misma... Mi madre. (RULFO, 1985, p. 65-66.)

Se a experiência de passado parece se opor à experiência do presente pelo trecho acima, a partir da inserção do conjunto de relatos que um narrador heterodiegético oferece sobre Comala, verificar-se-á que presente e passado são menos opostos que contínuos. Esse segundo narrador (heterodiegético) codivide a narrativa com a narração homodiegética de Juan Preciado e sempre toma a perspectiva das personagens na elaboração de sua voz. O presente da narração homodiegética e o passado da narração heterodiegética se complementam para dar 
conta das histórias de ilusão dos personagens de Comala. Chiampi (2008, p. 79) utiliza a terminologia de Gennete para caracterizar esse tipo de narração como metadiegética, quando se elabora "uma transição para um sistema de segundo grau. [...] A metadiégese vem a ser o nível da narrativa que fala do relato primeiro". A principal função da metadiégese em PP diz respeito ao rompimento com o ponto de vista monológico do realismo regionalista que descreve uma realidade como sinônimo de verdade. Em PP, a metadiégese é essencial à unidade da obra para unir o passado e o presente de Comala, uma vez que Juan Preciado não teve acesso ao primeiro, a não ser pela memória da mãe, que, entretanto, não se confunde com a verdade de Comala. Se a cidade natal da mãe de Juan Preciado era bela, o mesmo não se pode dizer das impressões do Padre Rentería, de Dorotea, de Dolores etc. A efusão das perspectivas dos vários habitantes de Comala problematiza a concepção essencialista de realidade, isto é, recusa-se a possibilidade de um real unívoco, de modo que o único elemento comum ao percurso de todos os personagens corresponde à ilusão de uma expectativa, que se converte em desilusão de sua experiência. Ilusão e desilusão também não se supõem antagônicas. Se a primeira diz respeito a uma distorção da percepção, uma interpretação falaciosa, a segunda é a sua contiguidade e não meramente sua consequência, porque pressupõe a presença daquela. Em outras palavras, não se chega a um resultado, aprisiona-se num processo. Passado e presente, ilusão e desilusão, a não disjunção entre tais elementos culmina na paridade vida e morte. Para Chiampi (2008), é a estrutura não disjuntiva que garante o efeito de encantamento do realismo maravilhoso:

\begin{abstract}
O insólito, em óptica racional, deixa de ser o 'outro lado', o desconhecido, para incorporar-se ao real: a maravilha é(está) (n)a realidade. Os objetos, seres ou eventos que no fantástico exigem a projeção lúdica de duas probabilidades externas e inatingíveis de explicação, são no realismo maravilhoso destituídos de mistério, não duvidosos quanto ao universo de sentido a que pertencem. Isto é, possuem probabilidade interna, tem causalidade no próprio âmbito da diégese e não apelam, portanto, à atividade de deciframento do leitor (CHIAMPI, 2008, p. 59).

$[\ldots]$

A questão consiste em apresentar o real, a norma, o 'verossímil romanesco', para facultar ao discurso a sua legibilidade como sobrenatural (a recíproca é verdadeira: os mirabilia também são legíveis como naturalia). Neste processo, nesta 'retórica de passagem', suspende-se a dúvida, a fim de evitar a contradição entre os elementos da natureza e da sobrenatureza. O efeito de encantamento do leitor é provocado pela percepção da contiguidade entre as esferas do real e do irreal pela revelação de uma causalidade onipresente, por mais velada e difusa que esteja. (CHIAMPI, 2008, p. 61.)
\end{abstract}

Defende-se aqui que o efeito de encantamento de que fala Chiampi (2008) é em PP alcançado pela comunicação implícita entre as vozes dos narradores, que revela o flagelo que se tornou Comala, mas principalmente pelo modo que as vozes arquitetam o relato e a descrição dos acontecimentos. A estrutura narrativa de PP rompe com o determinismo causalista pela maneira como presente e passado se aglutinam e pelas múltiplas perspectivas das personagens que se entrecruzam para formar uma imagem de Comala, subvertendo o modo de operacionalização do realismo tradicional - que acredita numa realidade objetiva - ainda que dele se aproprie para garantir a 
verossimilhança interna, naturalizando eventos sobrenaturais. É verdade que a correlação entre as formas narrativas homodiegética e heterodiegética são difíceis de aqui serem demonstradas pela extensão que necessitariam. Espera-se então que o leitor interessado contemple tal articulação na leitura de PP. Passa-se, assim, à observação da construção narrativa para que se verifique como é desenvolvida a verossimilhança interna:

\begin{abstract}
- Mire usted - me dice el arriero, deteniéndose -: ¿Ve aquella loma que parece vejiga de puerco? Pues detrasito de ella está la Media Luna. Ahora voltié para allá. ¿Ve la seja de aquel cerro? Véala. Y ahora voltié para este outro rumbo. ¿Ve la otra ceja que casi no se ve de los lejos que está? Bueno, pues eso es la Media Luna de punta a cabo. Como quien dice, toda la tierra que se puede abarcar com la mirada. $Y$ es de de él todo ese terrenal. El caso es que nuestras madres nos malparieron em un petate aunque éramos hijos de Pedro Páramo. (RULFO, 1985, p. 69.)
\end{abstract}

El calor me hizo despertar al filo de la medianoche. $Y$ el sudor. El corpo de aquella mujer hecho de tierra, envuelto em costras de tierra, se desbarataba como si estuviera derritiéndose em un charco de lodo. Yo me sentía nadar entre el sudor que chorreaba de ella y me faltó el aire que se necesita para respirar. Entonces me levanté. La mujer dormía. De su boca borbotaba un ruido de burbujas muy parecido al del estertor.

Salí a la calle para buscar el aire; pero el calor que me perseguía no se despegaba de mí.

Y es que no había aire; sólo la noche entorpecida y quieta, acalorada por la canícula de agosto.

No había aire. Tuve que sorber el mismo aire que salía de mi boca, deteniéndolo com las manos antes de que se fuera. Lo sentía ir y venir, cada vez menos; hasta que se hizo tan delgado que se filtró entre mis dedos para siempre.

Digo para siempre.

Tengo memoria de haber visto algo así como nubes espumosas haciendo remolino sobre mi cabeza y luego enjuagarme con aquella espuma y perderme em su nublazón. Fue lo último que vi. (RULFO, 1985, p. 125.)

Os trechos escolhidos correspondem respectivamente ao início e à metade da narrativa. No fragmento primeiro, Abundio (guia de Juan Preciado) comunica o referente "Media Luna" através de uma descrição visual da terra, considere-se exemplo crucial o período "toda la tierra que se puede abarcar com la mirada". Somam-se à descrição realista palavras da fala popular, como o aumentativo "terrenal" e o diminutivo "detrasito". Ambos os narradores abusam de descrições no início da narrativa sem que a elas sejam articulados quaisquer eventos incomuns. Sem dúvida, uma técnica que visa estabelecer uma objetividade para que, ao surgirem os elementos maravilhosos, os acontecimentos não entrem em contradição. É isso o que pode se observar no fragmento segundo, que trata da morte de Juan Preciado. O calor que o desperta é fruto da sensação térmica do corpo, bem como a constatação da mulher de terra que se desfaz em lama exige a atuação do campo visual. A audição do personagem denuncia um "ruido de burbujas" e os sentidos continuam latentes até à percepção da escassez de ar e sua "nublazón". O fim da vida é marcado pela falência dos sentidos: "fue lo último que vi"; Juan Preciado não reflete, na verdade, limita-se à descrição da experiência sem se afastar dos dados empíricos que a ela estavam ligados. A recorrência à percepção na remontagem dos eventos da história, materializada pela descrição sensorial, impede a antinonímia real versus sobrenatural. 
O incomum é inquestionável e naturalizado. Em PP, não é estranho que os vivos se comuniquem com os mortos ou que os mortos ainda se comportem como vivos, porque a organização interna da narrativa desfaz as operações do real lógico e recria um real onde as contradições da racionalidade não se verificam. Já mortos, Juan Preciado e Dorotea conversam:

[...] - ¿Qué viniste a hacer aquí?

- Ya te lo dije en principio. Vine a buscar a Pedro Páramo, que según parece fue mi padre. Me trajo la ilusión.

- ¿La ilusión? Eso cuesta caro. A mí me costo vivir más de lo debido. Pagué con eso la deuda de encontrar a mi hijo, que no fue, por decirlo así, sino una ilusión más; porque nunca tuve ningún hijo. Ahora que estoy muerta me he dado tiempo para pensar y enterarme de todo. Ni siquiera el nido para guardarlo me dio Dios. Sólo esa larga vida arrastrada que tuve, llevando de aquí para allá mis ojos tristes que siempre miraron de reojo, como buscando detrás de la gente, sospechando que alguien me hubiera escondido a mi niño. Y todo fue culpa de un maldito sueño. (RULFO, 1985, p. 129.)

Elege-se nesta análise o par ilusão-desilusão como o elemento integrante (no sentido de forma e fundo) de PP. Tal escolha é feita em consideração à estrutura narrativa (a não disjunção entre os tempos presente e passado) e ao conteúdo (a paridade entre a vida e a morte); vale ainda lembrar algo já mencionado, ilusão e desilusão operam em contiguidade e não em oposição. Pode-se ainda estabelecer uma correlação entre ilusão, passado, vida e desilusão, presente, morte. A conjunção " $e$ " que liga os dois polos funciona como um sinal de transição que não prevê o apagamento do primeiro polo. A desilusão, o presente e a morte não são o resultado do primeiro grupo, nem como fim nem como redefinição de perspectivas; mas aprisionamento. O efeito do encarceramento entre os polos correlatos é a imobilidade, a não expectativa de futuro. Nas palavras de Boixo (1985, p. 47):

En una de tantas dualidades de la novela, se enfrentan la ilusión y la desilusión. La esperanza de los personajes termina por convertirse em desesperanza, y su reflejo se muestra en esse pueblo de Comala presentado como un mundo acabado, sin futuro.

É o desejo de Juan Preciado de encontrar o pai que o leva ao conhecimento das barbáries do coronel Pedro Páramo e lhe dirige à morte; a fantasia da maternidade de Dorotea custa a sua vida; a obsessão de Pedro Páramo por Susanita, sua paixão irrealizada, causa a ruína de Comala.

Empreendida a análise sistêmica da obra e eleito o par ilusão-desilusão como unidade significativa, representação maior de PP, é tempo de investigar como tal elemento se comunica com os valores da sociedade contemporânea a sua produção para avaliar de que forma as representações da sociedade e da obra interagem e se o conhecimento das primeiras são essenciais para a caracterização do significado da segunda.

À relação de homonímia entre realidade e ficcionalidade correspondem as alusões a meia dúzia de nomes de pássaros, plantas e cidades do México; a forte 
presença do milho ao longo da narrativa, como no momento em que Damasio recorre a ajuda do patrão Pedro Páramo em nome dos revolucionários, dizendo: "ya estamos cansados de comer carne. [...] es dinero lo que necesitamos para mercar aunque sea una gorda con chile [torta apimentada de milho]" (RULFO, 1985, p. 178); mas, principalmente, às revoluções populistas que o México experimentou a partir de 1910. Em PP, menciona-se a Guerra Cristera e as revoluções villista e carrancista. Entretanto, para entender melhor a significância desses momentos políticos, é preciso conhecer Pedro Páramo com mais profundidade.

Pedro Páramo é dono da maior parte das terras de Comala e de toda a Media Luna. A conquista de sua fazenda foi feita pela invasão do território alheio; pelo casamento interessado com a mãe de Juan Preciado; através da usurpação da posse de outros etc. $O$ "terratenente" é ainda o patrocinador da igreja e empregador da força de trabalho de Comala, ao qual o povo, em sua miséria, está submetido. Os eventos históricos que menciona o texto consistiram em revoltas da massa popular contra o abuso de poder das oligarquias rurais, donas de latifúndios. Segundo informa Villalobos (1999, p. 172-173), por volta de 1910, um por cento dos proprietários possuíam $97 \%$ das terras disponíveis. Em PP, tal problema social não deixa de ser recuperado:

- Bien. ¿Qué se les ofrece? - volvió a preguntar Pedro Páramo.

- Como usté ve, nos hemos levantado en armas.

$-¿ Y$ ?

- Y pos eso es todo. ¿Le parece poco?

- ¿Pero por qué lo han hecho?

- Pos porque otros lo han hecho también. ¿No lo sabe usté? Aguárdenos tantito a que nos lleguen instrucciones y entonces averiguaremos la causa. Por lo pronto ya estamos aquí.

- Yo sé la causa - dijo otro -. Y si quiere se la entero. Nos hemos rebelado contra el gobierno y contra ustedes porque ya estamos aburridos de soportarlos. Al gobierno por rastrero y a ustedes porque no son más que unos móndrigos bandidos y mantecosos ladrones. Y del señor gobierno ya no digo nada porque le vamos a decir a balazos lo que le queremos decir.

- ¿Cuánto necesitam para hacer su revolución? - preguntó Pedro Páramo -. Tal vez you pueda ayudarlos. (RULFO, 1985, p. 167)

Rulfo (1985) vai além da simples recuperação da memória do conflito social mexicano e de sua causa ("nos hemos rebelado contra el gobierno y contra ustedes porque ya estamos aburridos de suportarlos") ao revelar o caráter desorganizado da revolução ("porque otros lo han hecho también") e a própria participação da classe média, haja vista a oferta financeira de Pedro Páramo. Córdova (1973), sobre a investigação da ideologia da Revolução Mexicana, argumenta que as massas não tinham um plano de reconstrução nacional, apenas lutavam por necessidades imediatas. O sociólogo destaca ainda que sequer percebeu Villa que o problema mexicano estava ligado à posse desigual de terra. Na verdade, o revolucionário tinha um ódio motivado contra os ricos por sua condição de explorado (CÓRDOVA, 1973, p. 157). Tomando o movimento maderista como exemplo da desarticulação dos revolucionários, destaca o investigador social: 
Su ideología y aun sus dirigentes, pese a haber tenido una legitimación y un reconocimiento a nivel nacional, no expresaron proyectos de desarrollo o de organización nacional. La proyección a esse nivel de sus posiciones o fue casual o se limitó a las demandas inmediatas. En ellos está ausente una idea precisa de un nuevo Estado; falta una concepción acabada de organización de la economía y de la sociedad; falta, en una palabra, una visión clara del futuro, y se mira más al pasado, como al mundo perdido que debe ser reconquistado. (CORDOBA, 1973, p. 143.)

O que se pode comentar sobre as expectativas imediatas, a ausência de uma visão clara de futuro e o aprisionamento ao passado de que fala Córdova (1973) na sociedade mexicana do início do século XX senão de sua correlação estreita com o par ilusão-desilusão, e sua reverberação no comportamento das personagens e na estrutura da narrativa, identificada na obra de Rulfo (1985)? Indubitavelmente, o escritor captou um aspecto do real que experimentara em sua sociedade e redimensionou-o em forma poética. Uma breve mirada sobre a biografia de Rulfo parece ainda indicar que tal processo se fez conscientemente. Boixo (1985, p. 15) revela que Rulfo perdeu toda a família em meio a Guerra dos Cristeros, vivendo em um orfanato dos dez aos catorze anos em solidão. É esse o momento histórico que Juan Rulfo (1985) reconstitui em Comala ou Jalisco (estado de sua infância e de mesma característica geográfica da cidade fictícia) em sua maturidade, emprestando ao narrador - Juan Preciado - seu primeiro nome e conduzindo-o na busca desastrosa de suas referências, iludido pelo sobrenome que promete o afeto do pai e concede-lhe o abandono. As ruínas de Comala foram compreendidas por Rulfo (Roffé apud BOIXO, 1985 , p. 19) em uma visita que fez a sua cidade natal, trinta anos após sua partida, ao encontrá-la desabitada, ainda que as ruas estivessem repletas de casuarinas e a noite tomada pelo ruído que o vento fazia nas folhas dessas árvores. Rulfo escreve Pedro Páramo entre os anos 1953 e 1954 e o principal fato que coopera para que se considere a empreitada de Rulfo consciente é o fracasso das propostas progressistas de reforma agrária, que colapsam definitivamente em 1950, fruto do desinteresse político que desconsiderara a problemática da concentração de terra (VILLALOBOS, 1999 , p. 174). Em PP, a ruína do ambiente rural é resultado do desleixo planejado de Pedro Páramo devido ao rancor que gerou contra o povo que não entendeu o seu luto pela morte de Susanita:

La Media Luna estaba sola, em silencio. Se caminaba con los pies delcalzos; se hablaba em voz baja. Enterraron a Susana San Juan y pocos en Comala se enteraron. Allá había feria. Se jugaba a los gallos, se oía la música; los gritos de los borrachos y de las loterías. Hasta acá llegaba la luz del pueblo, que parecía una aureola sobre el cielo gris. Porque fueron días grises, tristes para la Media Luna. Don Pedro no hablaba. No salía de su cuarto. Juró vengarse de Comala:

- Me cruzaré de brazos y Comala se morirá de hambre.

Y así lo hizo. (RULFO, 1985, p. 186-187.)

A curta análise que se fez de PP não teve a pretensão de totalizar a obra, mesmo porque impossível, uma vez que seu significado se atualiza através da recepção, que histórica, supõe a contínua reorganização dos sistemas de 
representação social. O ensaio é ainda devedor de um cruzamento entre PP e as séries literárias adjacentes, trabalho que resultaria relevante para o enriquecimento da discussão do realismo, sobretudo porque é PP considerado realista mágico, espécie de renovação do realismo regionalista que se fazia na América Latina. Assumidas as maiores limitações, é momento de refletir a justeza da classificação realista para a obra de Juan Rulfo (1985).

Se toda obra guarda uma relação com o real histórico, isto não é suficiente para caracterizá-la realista. Não se deve confundir o princípio de seleção do real (ISER, 2002, p. 279), comum a toda a obra, pois inscrita historicamente, com o conceito de realismo. Insiste-se aqui no realismo artístico como um procedimento no qual o sentido só é alcançado pela consideração da semelhança entre a estrutura linguística e as representações históricas do contexto de produção da obra. Daí, conclui-se que:

Pedro Páramo não é realista. Não se questiona que a forma social da ilusãodesilusão seja convertida em forma poética em PP, mas o conhecimento do conflito social mexicano não é essencial para a significação do romance, visto que ele próprio o remonta, tanto no nível da história quanto no nível do discurso. PP revela internamente as referências histórico-ideológicas que Ihe servem de problematização, saiba o leitor sua correlação com o mundo externo ou não. Definir se PP merece o adjetivo realista é menos importante do que assinalar como a obra problematiza o conceito de realismo artístico. Ainda que assumindo o princípio de exposição de perspectiva a partir da sistematização de Jakobson (1978), o analista displicente poderia apontar diversas justificativas: uma renovação do cânone regionalista que tomava a realidade como objetiva e unívoca (caso $\mathrm{A} 1$ de $\mathrm{A}$ e oposto a $\mathrm{C}$ em Jakobson); um juízo de superioridade em relação aos antecedentes por apresentar uma visão mágica da América (caso B1 de B); coerência de construção (E), que sobrepõe o aspecto interno ao externo, procedimento tecnicamente realizado pelo romance de Rulfo (1985) pelo modo e voz dos narradores e pela sobrenaturalização do real, geradores de encantamento. PP congrega todas as três hipóteses, mas elas é que não abarcam o realismo artístico em um conceito.

Pedro Páramo é realista. Talvez a posição do analista, brasileiro, latinoamericano, seja a causa de um possível equívoco cuja razão não é nenhuma justificativa genética ou geográfica. Pedro Páramo não está sozinho no México nem encontra análogos apenas na Hispano-América. A Comala de Juan Rulfo se assemelha à representação do sertão brasileiro. Há de se considerar o coronelismo nas sociedades rurais brasileiras e as revoltas campesinas do México, que correspondem, salvas as particularidades, à Guerra de Canudos ou mesmo ao cangaço liderado por Lampião. E as referências não se esgotam na História, porém são também parte da Literatura (Os Sertões, Morte e Vida Severina, Vidas Secas etc.). O analista não pode deixar de reconhecer que a estrutura social retratada em PP estabelece comunicação com o seu imaginário. Em decorrência disso, não se consegue precisar a relevância dos elementos extraverbais em PP, ainda que esteja explícita a dimensão com que eles são trabalhados na poesia de Juan Rulfo (1985).

Mais significativo é reconhecer como Juan Rulfo (1985) efetua a reatualização do gênero romance ao revelar influências da Literatura Europeia (as vanguardas, Kafka, 
Proust etc.) e o redimensionamento destas através do diálogo com a tradição local, incluindo-se no termo tradição as séries literárias e os valores sociais. Obra plural, como toda obra grande, Pedro Páramo é uma forma poética condensada a partir de uma experiência pessoal contextualizada historicamente que, sem abandonar o particular, eleva-se ao universal, extrapolando os limites do realismo tomado como escola ou procedimento artístico.

Definir Pedro Páramo como realista ou não é menos importante que reconhecêlo como alternativa a uma indagação constante que motiva e desconforta críticos e teóricos: a resposta ao que é a Literatura.

\section{Referências}

BLIKSTEIN, Izidoro. Kaspar Hauser ou a Fabricação da Realidade. São Paulo: Cultrix, 1995.

BOIXO, J. C. GONZÁLEZ. Introduccion. In: RULFO, Juan. Pedro Páramo. Madrid: Catedra, 1985.

CHIAMPI, Irlemar. O Realismo Maravilhoso. São Paulo: Perspectica, 2008.

CÓRDOVA, Arnaldo. La Ideología de la Revolución Mexicana. México, D.F.: Era, 1973.

CULLER, Jonathan. Teoria Literária: uma introdução. São Paulo: Beca, 1999.

ISER, Wolfgang. Os atos de fingir ou o que é fictício no ficcional. In: LIMA, Luiz Costa (Org.). Teoria da Literatura em Suas Fontes, vol. 2. Rio de Janeiro: Civilização Brasileira, 2002.

JAKOBSON, Roman. Do Realismo Artístico. In: Teoria da Literatura: formalistas russos. Porto Alegre: Globo, 1978.

LIMA, Luiz Costa. A Metamorfose do Silêncio. Rio de Janeiro: Eldorado, 1974. Dispersa Demanda. Rio de Janeiro: Francisco Alves, 1981.

RULFO, Juan. Pedro Páramo. Madrid: Catedra, 1985.

VILLALOBOS, J. U. Guerra. A concentração de terras na América Latina: um estudo de caso do México (1910 - 1950). Acta Scientiarum, Maringá, 1999. Disponível em: <http://periodicos.uem.br/ojs/index.php/ActaSciHumanSocSci/article/viewArticle/4204 >. Acesso em 5 jan. 2011. 


\section{Title}

The Limits of Artistic Realism in Pedro Páramo, by Ruan Julfo

\section{Abstract}

In the light of Theory of Literature, this essay investigates the concept of artistic realism in fiction starting from the discussion about reference and linguistic sign, based on the category of social representation of Luiz Costa Lima $(1981 ; 1974)$ and the theory of aesthetic effect of Wolfgang Iser (2002). The aim consists of the dialog between the conception of artistic realism developed by the theoretical reflexion and the particular features reached through the analysis of the novel Pedro Páramo, by Juan Rulfo (1985), in order to assess what elements are involved in characterizing a work as realist.

\section{Keywords}

Theory of Literature. Artistic realism. Fiction. Pedro Páramo.

Recebido em 18.04.2011. Aprovado em 11.07.2011. 